\title{
12. LITHOLOGIC STRATIGRAPHY AND CLAY MINERALOGY OF THE WESTERN CARIBBEAN AND EASTERN EQUATORIAL PACIFIC, LEG 68, DEEP SEA DRILLING PROJECT ${ }^{1}$
}

\author{
Herman B. Zimmerman, Department of Civil Engineering, Union College, Schenectady, New York
}

\begin{abstract}
Complete and virtually undisturbed sections of late Neogene and Quaternary sediment were recovered by the hydraulic piston corer from Leg 68 sites in the western Caribbean and eastern equatorial Pacific. Lithologic stratig. raphy of Site 502 records the changing paleoceanography of the western Caribbean. Associated with the emergence of the Isthmus of Panama is the weakening of the west-flowing Caribbean Current. This is reflected in an abrupt lithofacies change, with a marine authigenic-volcanic facies of late Miocene being replaced in the Pliocene by continental detritus of the Rio Magdalena. At Site 503, on the northern flank of the Galapagos Rise, almost the entire sediment section consists of a marine authigenic-hydrothermal facies.
\end{abstract}

\section{INTRODUCTION}

Leg 68 of the Deep Sea Drilling Project (DSDP) had as its primary goal the recovery of undisturbed sections of unconsolidated sediment using the recently developed hydraulic piston corer (HPC). The HPC has been fully successful in this task. The test of this instrument involved the recovery and comparison of two Neogene sediment sections from sites previously drilled by conventional rotary techniques. Previous sampling at Site 154 (Leg 15) in the western Caribbean Sea and Site 83 (Leg 9) in the eastern equatorial Pacific (Fig. 1) recovered sediment that had been greatly disturbed by the rotary drilling process. Leg 68 deployed the HPC at Sites 502 and 503 and recovered apparently continuous and undisturbed sedimentary sections of late Neogene and Quaternary age.

\section{METHODS}

\section{Lithologic Correlation between Holes (Site 502)}

Four holes were cored at Site 502 to insure that a complete sedimentary section would be recovered by the HPC. Lithologic correlation between holes was made aboard ship by microscopic smear slide analyses, sediment color determination, carbonate analyses, and distinctive ash layers (site chapter, Site 502). Many of the ashes were difficult to correlate because they were similar in gross character when analyzed by shipboard techniques. In three cases, however, ashes proved to be excellent marker horizons:

1) One gray-colored ash was distinctive and easily correlatable between Holes $502(30.18 \mathrm{~m})$ and 502B $(30.00 \mathrm{~m})$ (all other ashes were dark in color).

2) Closely spaced pairs (doublets) of ash layers were distinctive between Holes $502(131.47 \mathrm{~m}-131.76 \mathrm{~m}), 502 \mathrm{~A}(130.10 \mathrm{~m}-130.40 \mathrm{~m})$, and $502 \mathrm{C}(127.66 \mathrm{~m}-127.92 \mathrm{~m})$.

3) An additional doublet of ash layers was correlated between Holes $502(166.18 \mathrm{~m}-166.38 \mathrm{~m})$ and $502 \mathrm{~A}(162.20 \mathrm{~m}-162.35 \mathrm{~m})$.

Sub-bottom depths of samples from Hole 502 have been corrected to sub-bottom depths in Hole 502A (Table 1).

The clay-mineral crystallinity index (to be described) proved effective for more detailed correlations. The best example is the abrupt

\footnotetext{
${ }^{1}$ Prell, w. L., Gardner, J. V., et al., Init. Repts. DSDP, 68: Washington (U.S. Govt. Printing Office)
}

decrease in the crystallinity index at 201 meters, Holes 502 and 502A (Fig. 2).

\section{Sample Preparation and Mineral Identification}

An initial set of samples was taken aboard ship to represent all sediment facies and stratigraphic horizons in the cores. Subsequent sampling after the cruise filled in gaps or critical stratigraphic sections where preliminary studies indicated that additional detail was needed. An additional group of samples from Sites 83 and 154 were studied for comparison of results under uniform laboratory conditions. In all, over 200 samples at an average interval of about 2.5 meters downcore were analyzed by standard $\mathrm{x}$-ray diffraction (XRD) procedures.

Calcium carbonate was removed by overnight treatment with 0.6 $N$ acetic acid solution, followed by successive decantation until flocculation ceased (usually three repetitions), then settling in accordance with calculated times to allow separation of the 2-37 $\mu \mathrm{m}$ (silt) and $<2$ $\mu \mathrm{m}$ (clay) size fractions. The two separate suspensions were then concentrated by decantation to remove excess water, and the sediment pastes smeared on glass slides (Gibbs, 1965). Each slide was analyzed by XRD both before and after ethylene glycol solvation $(1 \mathrm{hr}$. at $60^{\circ} \mathrm{C}$ ). The clay slides were run through a scan of $3^{\circ}$ to $14^{\circ} 2 \theta$ with a slow scan speed in the $24^{\circ}$ to $26^{\circ} 2 \theta$ range; the silt slides were run through a range of $3^{\circ}$ to $35^{\circ} 2 \theta$ at a scan speed of $2^{\circ} 2 \theta / \mathrm{min}$. Analysis was performed with a General Electric XRD-7 diffractometer with nickel-filtered $\mathrm{CuK}_{\alpha}$ radiation.

Major mineral phases on the clay slide were identified by their basal reflections. The area under the $7.1 \AA$ peak was used as an indicator of the abundance of chlorite and kaolinite, with the slow-scan method of Biscaye (1964) applied as a means of identifying and separating these two minerals. Illite (or mica) was recognized by a welldefined peak at $10 \AA$ that was unaffected by ethylene glycol solvation. A broad $17 \AA$ peak after solvation was routinely assigned to smectite (montmorillonite). Reynolds and Hower (1970) have demonstrated that a $17 \AA$ A peak may represent pure montmorillonite or a mixed-layer mica-montmorillonite, where decreasing peak intensity, resulting in a broad peak, represents an increasing abundance of mica layers (see also, Hayes, 1973; Eslinger and Savin, 1976). For this investigation the area under the $17 \AA$ peak is employed as a relative measure of "smectite" abundance.

Semiquantitative estimates of the relative amounts of crystalline clay components were determined by concentration factors described by Biscaye (1965), in which proportions of smectite, kaolinite, illite, and chlorite are normalized to $100 \%$. Abundances of other components were not determined, although other measurements and mineral ratios (to be described) were determined from the XRD trace of silt-size material. These methods give results that are internally consistent and therefore allow an interpretation of the relative changes in mineral content occurring over long time spans. 


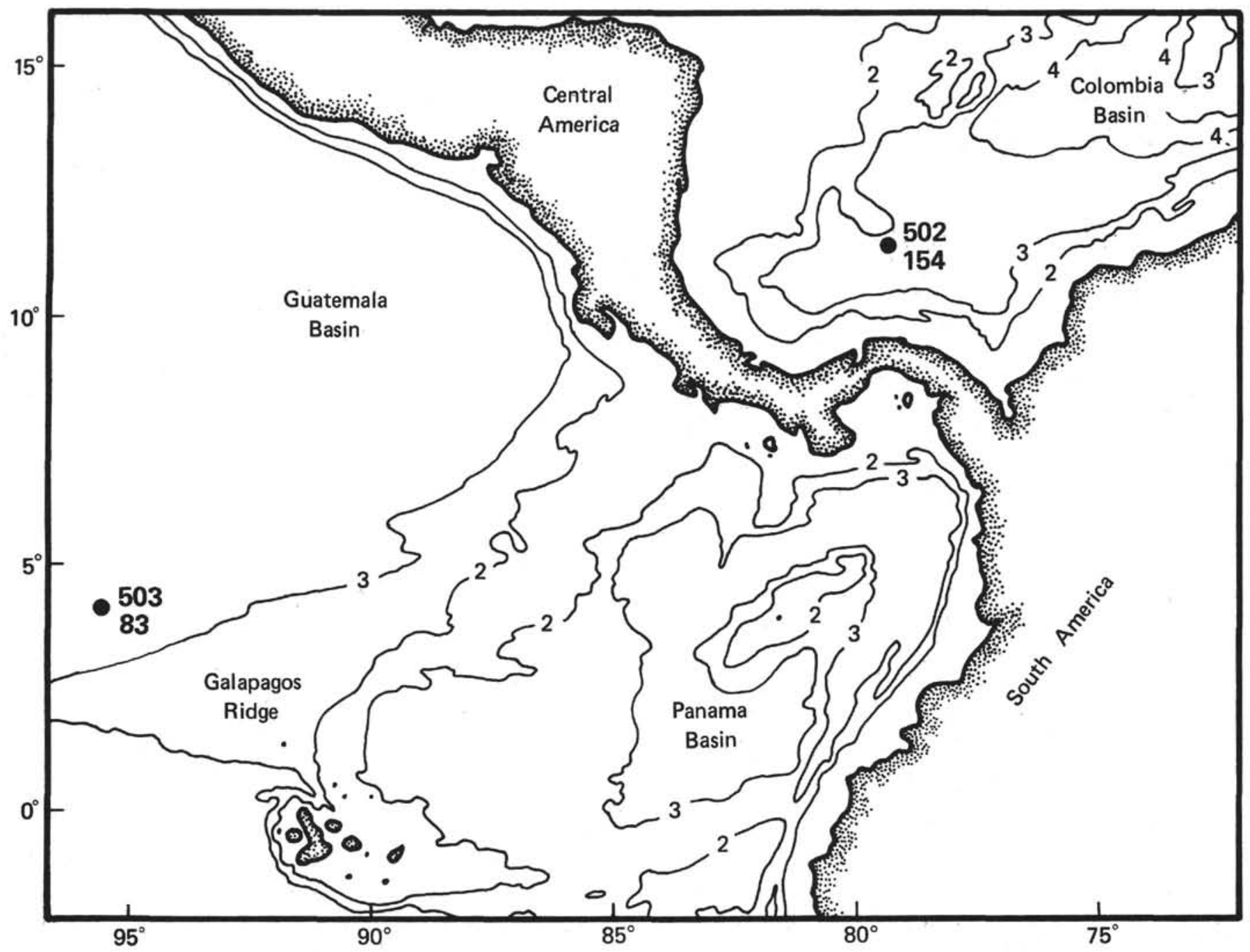

Figure 1. Index chart for the western Caribbean and eastern equatorial Pacific. (Contours in $\mathrm{km}$. Sites 502/154 and Sites 503/83 lie within the site symbol.)

\section{RESULTS SITE 502}

\section{Clay Minerals}

At Site 502 the most prevalent feature of the clay mineralogy is the trend of increasing smectite abundance with depth (Fig. 2). In the upper 25 meters of this sediment section, smectite abundance averages about $40 \%$; this increases more or less consistently with depth to an average of about $75 \%$ in the lower portion of the section. This trend is accompanied by a concomitant decrease in the other clay mineral species (illite, chlorite, and kaolinite). Palygorskite was also identified in small amounts throughout this section.

Clay mineral abundance provides a rough correlation with the subunits described by smear slide examination, but does not appear to be a stratigraphic tool of significant resolution at this location. First-order variation in the trends of clay mineral abundance is related to the presence of volcanic ash layers or concentrations of dispersed ash as noted in smear slide examination. Individ- ual ash layers are most often accompanied by an apparent decrease in smectite abundance, especially in the upper portion of the section. This may, however, be an effect of small crystal size, poor crystallinity, mixed layering, or dilution with ash components.

Inspection of the diffactograms revealed the potential of the total clay reflectivity as a potent stratigraphic measure. I have chosen the term "crystallinity index" (Fig. 2) because of the covariance and contribution of all the clay mineral peak areas to this measure. This does not reflect only the smectite crystallinity (Biscaye, 1965), nor is it solely a measure of the extent of mixedlayer presence (Reynolds and Hower, 1970). Figure 3 illustrates the difference in the nature of the diffractogram patterns between sediments of high and low crystallinity indices. Although the two diffractogram traces indicate approximately the same relative abundance of clay mineral species, the two patterns are quite different in total reflectivity. The most convenient way to describe this was to measure the sum of the areas (in 
Table 1. Sample location key-Site 502.

\begin{tabular}{|c|c|c|c|c|}
\hline Sample No. & $\begin{array}{l}\text { Core/Section } \\
\text { (level in } \mathrm{cm} \text { ) }\end{array}$ & $\begin{array}{l}\text { Sub-bottom } \\
\text { Depth }(m)\end{array}$ & $\begin{array}{l}\text { Corrected }^{\mathrm{a}} \\
\text { Depth (m) }\end{array}$ & Comments \\
\hline & Hole 502 & & & \\
\hline 1 & $2-3,110$ & 4.47 & & \\
\hline 2 & $2-3,19$ & 3.56 & & \\
\hline 3 & $16-1,130$ & 63.23 & & \\
\hline 4 & $17-1,111$ & 67.41 & & \\
\hline 5 & $31-1,90$ & 127,00 & 125.63 & \\
\hline 6 & $32-1,70$ & 131.16 & 129.79 & $20 \mathrm{~cm}$ above ash \\
\hline 7 & $44-1,80$ & 184.03 & 180.16 & \\
\hline 8 & $46-1,135$ & 193.30 & 189.43 & ash/clay \\
\hline 9 & $48-1,51$ & 201.11 & 197.24 & \\
\hline 10 & $49-1,21$ & 205.49 & 201.62 & \\
\hline 147 & $50-1,31$ & 210.01 & 206.14 & \\
\hline 170 & $9-2,32$ & 33.00 & & zeolite-bearing \\
\hline \multirow[t]{2}{*}{185} & $34-2,89$ & 142.07 & 140.70 & \\
\hline & Hole 502A & & & \\
\hline 21 & $1-1,101$ & 0.91 & & \\
\hline 22 & $2-1,120$ & 3.10 & & \\
\hline 23 & $2-2,100$ & 4.33 & & \\
\hline 24 & $3-2,50$ & 8.20 & & \\
\hline 25 & $4-1,101$ & 11.64 & & \\
\hline 26 & $5-2,50$ & 17.05 & & \\
\hline 27 & $6-2,100$ & 21.58 & & \\
\hline 28 & $7-2,100$ & 26.14 & & \\
\hline 29 & $8-2,100$ & 30.50 & & \\
\hline 30 & $19-2,98$ & 78.93 & & \\
\hline 31 & $20-2,100$ & 83.47 & & \\
\hline 32 & $21-2,100$ & 87.96 & & \\
\hline 33 & $22-2,103$ & 92.44 & & \\
\hline 34 & $23-2,99$ & 95.75 & & \\
\hline 35 & $24-2,100$ & 101.21 & & \\
\hline 36 & $25-2,97$ & 105.49 & & \\
\hline 37 & $26-2,100$ & 109.93 & & \\
\hline 38 & $27-2,100$ & 114.40 & & \\
\hline 39 & $28-2,50$ & 118.14 & & \\
\hline 40 & $29-2,102$ & 121.82 & & \\
\hline 41 & $30-2,100$ & 125.28 & & \\
\hline 42 & $32-1,100$ & 129.30 & & $60 \mathrm{~cm}$ above ash \\
\hline 43 & $33-1,100$ & 132.27 & & \\
\hline 44 & $34-2,50$ & 136.30 & & \\
\hline 45 & $35-2,100$ & 139.35 & & \\
\hline 46 & $36-2,48$ & 142.66 & & \\
\hline 47 & $37-2,51$ & 144.45 & & \\
\hline 48 & $38-1,100$ & 146.58 & & \\
\hline 49 & $39-1,100$ & 148.10 & & \\
\hline 50 & $40-1,100$ & 151.18 & & \\
\hline 51 & $41-2,50$ & 154.20 & & \\
\hline 52 & $42-1,100$ & 156.80 & & \\
\hline 53 & $43-1,100$ & 159.30 & & \\
\hline 54 & $44-2,50$ & 162.90 & & \\
\hline 55 & $45-1,100$ & 164.69 & & \\
\hline 56 & $46-1,100$ & 166.99 & & \\
\hline 57 & $47-1,100$ & 168.98 & & \\
\hline 58 & $48-1,100$ & 172.13 & & \\
\hline 59 & $50-1,100$ & 176.16 & & \\
\hline 60 & $51-1,100$ & 179.30 & & \\
\hline 61 & $52-1,100$ & 181.64 & & \\
\hline 62 & $53-1,100$ & 183.49 & & \\
\hline 63 & $54-1,100$ & 185.60 & & \\
\hline 64 & $55-1,100$ & 188.15 & & $25 \mathrm{~cm}$ above ash \\
\hline 65 & $56-1,100$ & 189.98 & & \\
\hline 66 & $57-1,120$ & 192.30 & & \\
\hline 67 & $58-1,100$ & 194.00 & & $60 \mathrm{~cm}$ above ash \\
\hline 68 & $60-1,100$ & 198.22 & & $15 \mathrm{~cm}$ below ash \\
\hline 69 & $61-1,100$ & 199.87 & & \\
\hline 70 & $62-1,40$ & 201.60 & & \\
\hline 71 & $63-1,120$ & 204.27 & & ash-bearing clay \\
\hline 72 & $65-1,120$ & 208.32 & & \\
\hline 73 & $66-1,100$ & 210.05 & & \\
\hline 74 & $67-1,50$ & 211.50 & & ash-bearing clay \\
\hline 75 & $68-1,100$ & 213.78 & & ash-bearing clay \\
\hline 148 & $66-2,12$ & 210.67 & & ash-bearing clay \\
\hline 149 & $67-1,73$ & 211.73 & & ash-bearing clay \\
\hline 150 & $68-2,24$ & 214.52 & & ash-bearing clay \\
\hline 171 & $6-2,47$ & 21.05 & & ash and zeolite-bearing \\
\hline 172 & $7-2,63$ & 25.77 & & zeolite-bearing \\
\hline 173 & $10-2,100$ & 39.60 & & $40 \mathrm{~cm}$ above ash \\
\hline 174 & $10-2,145$ & 40.05 & & \\
\hline 175 & $10-3,2$ & 40.12 & & ash layer \\
\hline 176 & $32-2,40$ & 130.42 & & between ash layers \\
\hline 178 & $58-2,13$ & 194.63 & & ash layer \\
\hline 196 & $63-1,39$ & 203.46 & & \\
\hline 197 & $61-1,129$ & 200.59 & & \\
\hline
\end{tabular}

Table 1. (Continued).

\begin{tabular}{|c|c|c|c|c|}
\hline Sample No. & $\begin{array}{l}\text { Core/Section } \\
\text { (level in cm) }\end{array}$ & $\begin{array}{l}\text { Sub-bottom } \\
\text { Depth (m) }\end{array}$ & $\begin{array}{l}\text { Corrected }^{\mathrm{a}} \\
\text { Depth (m) }\end{array}$ & Comments \\
\hline & Hole 502B & & & \\
\hline 11 & $8-3,50$ & 31.08 & & \\
\hline 12 & $9-2,50$ & 34.86 & & \\
\hline 13 & $11-2,50$ & 43.34 & & \\
\hline 14 & $12-3,50$ & 48.85 & & \\
\hline 15 & $13-2,45$ & 52.10 & & \\
\hline 16 & $14-2,100$ & 56.93 & & \\
\hline 17 & $15-1,100$ & 59.95 & & \\
\hline 18 & $16-1,50$ & 63.60 & & \\
\hline 19 & $17-2,50$ & 69.50 & & \\
\hline \multirow[t]{2}{*}{20} & $18-2,50$ & 74.14 & & \\
\hline & Hole $502 \mathrm{C}$ & & & \\
\hline 76 & $28-1,99$ & 211.20 & & \\
\hline 77 & $29-1,80$ & 214.00 & & ash-bearing clay \\
\hline 78 & $30-1,20$ & 215.15 & & ash-bearing clay \\
\hline 79 & $31-1,120$ & 217.50 & & \\
\hline 80 & $32-1,70$ & 219.80 & & $30 \mathrm{~cm}$ above ash \\
\hline 81 & $33-1,80$ & 222.47 & & \\
\hline 82 & $34-1,80$ & 224.00 & & \\
\hline 83 & $35-1,48$ & 226.18 & & \\
\hline 84 & $36-1,30$ & 226.92 & & \\
\hline 85 & $37-1,5$ & 227.75 & & \\
\hline 152 & $28-2,43$ & 212.14 & & ash \\
\hline 154 & $28-2,78$ & 212.49 & & \\
\hline
\end{tabular}

a All depths below $160 \mathrm{~m}$ have been adjusted by $+3.87 \mathrm{~m}$; all depths between $120-160$ $\mathrm{m}$ have been adjusted by $+1.37 \mathrm{~m}$ for Hole 502 .

$\mathrm{mm}^{2}$ ) under the $17 \AA, 10 \AA$, and $7 \AA$ peaks (solvated) after multiplying by the factors of Biscaye (1965). The result is the "crystallinity index" which, when plotted against depth (Fig. 2), is a sensitive stratigraphic tool for this section.

In unison with ash and the more muted clay mineral abundance, the crystallinity index is highly variable. Other trends, however, are discernible. In Units A and B (Fig. 2), the index averages about 2000 , but at the Unit $\mathrm{B} / \mathrm{C}$ boundary $(113 \mathrm{~m})$ the index rises to an average of about 3000 . A sharp decrease is noted at 201 meters; indeed, this depth may more accurately represent the Unit C/D boundary than the original shipboard determination $(210 \mathrm{~m})$, which was based on smear slide examination. The boundary at 201 meters effectively divides the sediment section into two clay mineral facies based on the perfection of crystallinity (or the extent of mixed layering). It is noteworthy that the nature of the sediments above 201 meters are typically a "terrigenous/Atlantic" association (i.e., well-crystallized smectite with common-to-abundant kaolinite, chlorite, and illite; Fig. 5, 502A-11.64 $\mathrm{m}$ and 502A-139.35 m), while below this depth the sediments more closely resemble a "marine/Pacific" association and are herein termed the marine authigenic-volcanic facies (poorly crystallized smectite with little or no illite, kaolinite, or chlorite; Fig. 5, 502C-219.80 m). A somewhat similar observation of "continental" or "oceanic" associations was made for the south and equatorial Pacific by Heath (1969) and for the South Atlantic by Zimmerman (1977).

\section{Silt Mineralogy}

The key stratigraphic factor found in the noncarbonate silt-size fraction is the quartz/plagioclase ratio (Fig. 2) as calculated from the peak height of quartz $(3.34 \AA)$ and plagioclase $(3.2 \AA)$. The ratio averages 


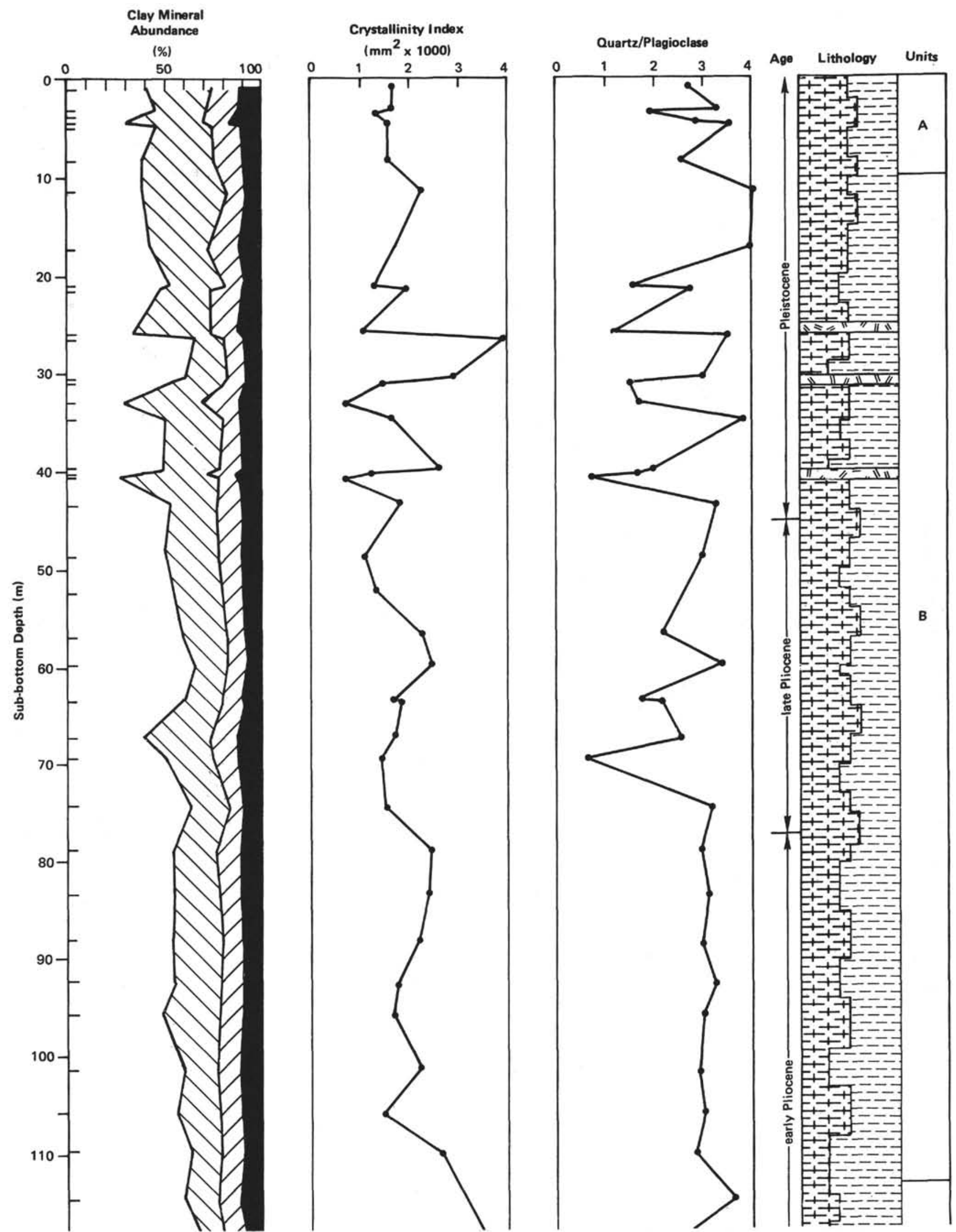

Figure 2. Summary of lithostratigraphic and mineralogical data for HPC Site 502, Leg 68, western Caribbean Sea. (This chart represents a compilation of data from Holes 502, 502A, 502B, 502C.) 


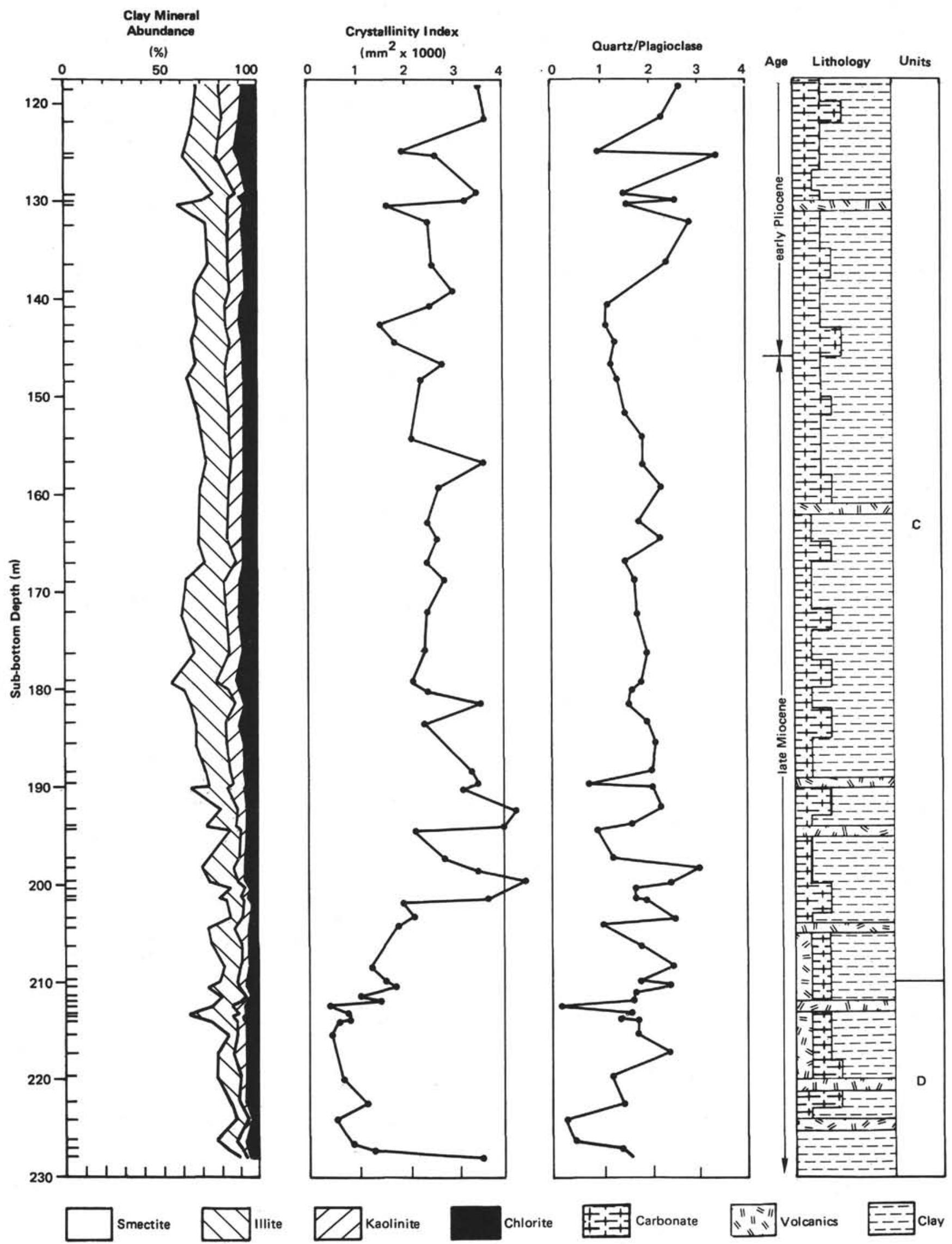

Figure 2. (Continued). 


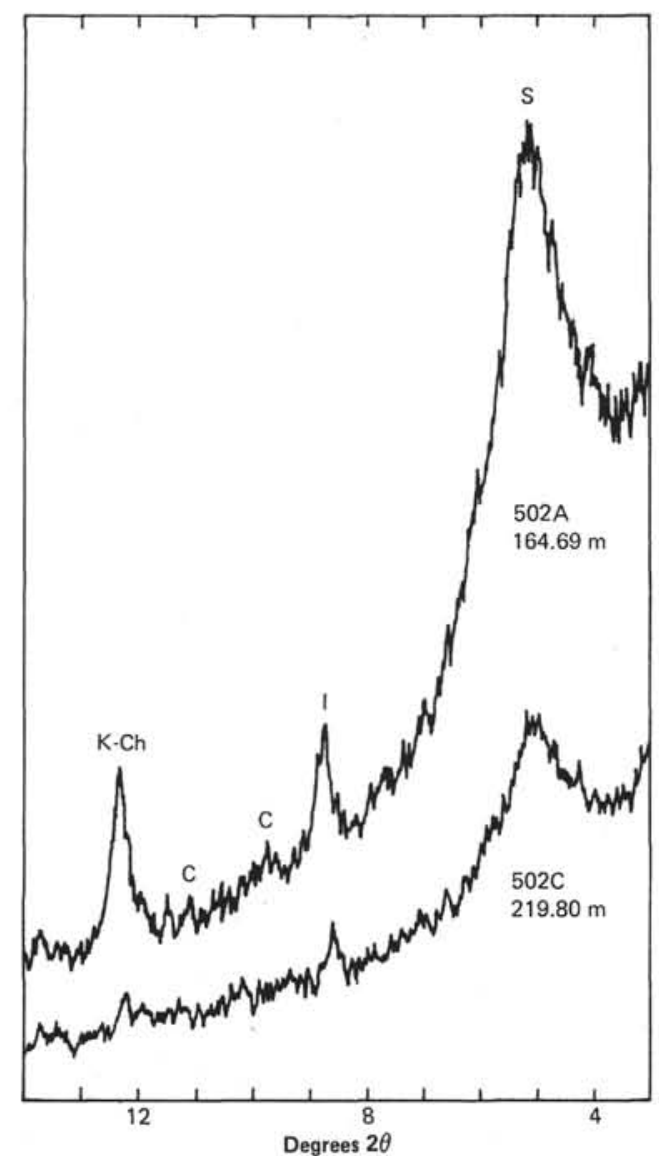

Figure 3. Selected diffractograms (glycolated) illustrating the nature of the "crystallinity index." Samples have approximately the same clay mineral abundances but different crystallinities. (Peaks indicated are: $\mathrm{S}=$ smectite, $\mathrm{I}=$ illite, $\mathrm{C}=$ clinoptilolite, and $\mathrm{K}-\mathrm{Ch}$ $=$ kaolinite/chlorite. Sample designations are given by hole and sub-bottom depth.)

about 3 in the upper portion of the section and then decreases to about 2 just below the Unit B/C boundary (approximately $125 \mathrm{~m}$ sub-bottom). In the vicinity of ash the ratio declines abruptly to less than 1 , indicating relatively high plagioclase abundances. Alkali feldspar is also associated with the volcanic ashes (Fig. 4).

All other minerals of the silt fraction are found in trace amounts, except clinoptilolite, which is especially common at a depth of about 210 meters where it occurs with phillipsite. Small amounts of analcite (150-170 m), cristobalite (below $215 \mathrm{~m}$ ), bassanite? (80-145 m), and amphibole (throughout) have all been identified at this site.

\section{Volcanic Ashes}

Closely spaced samples from ash layers were prepared as bulk samples from the insoluble residue $(<37$ $\mu \mathrm{m}$ fraction); two sets of these diffractograms are illustrated in Figure 4. The ash layer at Hole 502A $(194.70 \mathrm{~m})$ is from Unit C, within a clay matrix of wellcrystallized (or little-interlayered) smectite. The host sediment was sampled at 194.00 meters, $70 \mathrm{~cm}$ above the ash layer, and shows no ash attributes. Both the ash $(194.70 \mathrm{~m})$ and a sediment sample immediately above $(194.55 \mathrm{~m})$ are distinguished from the host sediment by somewhat lower crystallinity indices $(\sim 2100)$ and lower quartz/plagioclase ratios $(\sim 1)$. Alkali feldspar is also prominent, with phillipsite present only within the ash layer itself.

The host sediment of a second ash layer within Unit D at 212.11 meters exhibits the poorly crystallized clay minerals typical of that unit. Within the ash itself (sample, $212.14 \mathrm{~m}$ ), the clay crystallinity index is especially low $(\sim 500)$ and the prominent plagioclase peak results in an extremely low quartz/plagioclase ratio $(\sim 0.2)$. Phillipsite is not associated with this ash, although clinoptilolite is present in minor amounts in the host sediment. It is noteworthy that the nature of the clay minerals seems unrelated to the presence of vitric ash layers. Some diagenetic activity is noted by the presence of zeolite minerals, but diagenetic alteration of vitric ash does not appear to be an important smectite source.

\section{Comparison with Site 154}

Site 154 (Leg 15) is located just off the topographic high in the southwestern Colombian Basin on which Site 502 is located (Leg 68). The latter was cored in a water depth of 3051 meters whereas Site 154 was drilled at a water depth of 3338 meters. The sediments of Site 154 are divisible into a lower "volcanic-terrigenous" sequence and an upper "pelagic" sequence of marl ooze and clay (Edgar, Saunders, et al., 1973).

XRD analyses were performed on selected samples from these two major lithofacies. The upper pelagic unit exhibits the high clay mineral "crystallinity index" and high quartz/plagioclase ratio of the upper three units of Site 502, the terrigenous/Atlantic association (Fig. 5, $502 \mathrm{~A}-11.64 \mathrm{~m}$ and $502 \mathrm{~A}-139.35 \mathrm{~m}$ ), whereas the lower volcanic-terrigenous unit described from Site 154 resembles Unit D of Site 502, the marine authigenic-volcanic facies (Fig. 5, 502C-219.80 m). The change in facies occurs abruptly within earliest Pliocene time at 167 meters (Hole 154) and 153 meters (Hole 154A), whereas it occurs at 201 meters at Site 502 in sediments dated late Miocene. The different position of this stratigraphic boundary in the two sites does not appear to be caused by disturbances of rotary drilling, but may be caused by an unidentified unconformity at Site 154 or differential uplift of the sites (see discussion).

Noteworthy within the upper pelagic sequence of Site 154 are pockets of coarse volcanic sand. These are attributed to reworking of the older sequence or to local turbidites (Edgar, Saunders, et al., 1973). The use of the HPC at Site 502 suggests that these are actually younger volcanogenic debris similar in stratigraphic position to volcanic ash layers of Unit B at Site 502 .

\section{RESULTS SITE 503}

Site 503 is located in the eastern equatorial Pacific at approximately the same position and depth $(3650 \mathrm{~m})$ as Site 83 (Leg 9, Hays et al., 1972). The sedimentary section at these sites is similar and consists of a uniform 


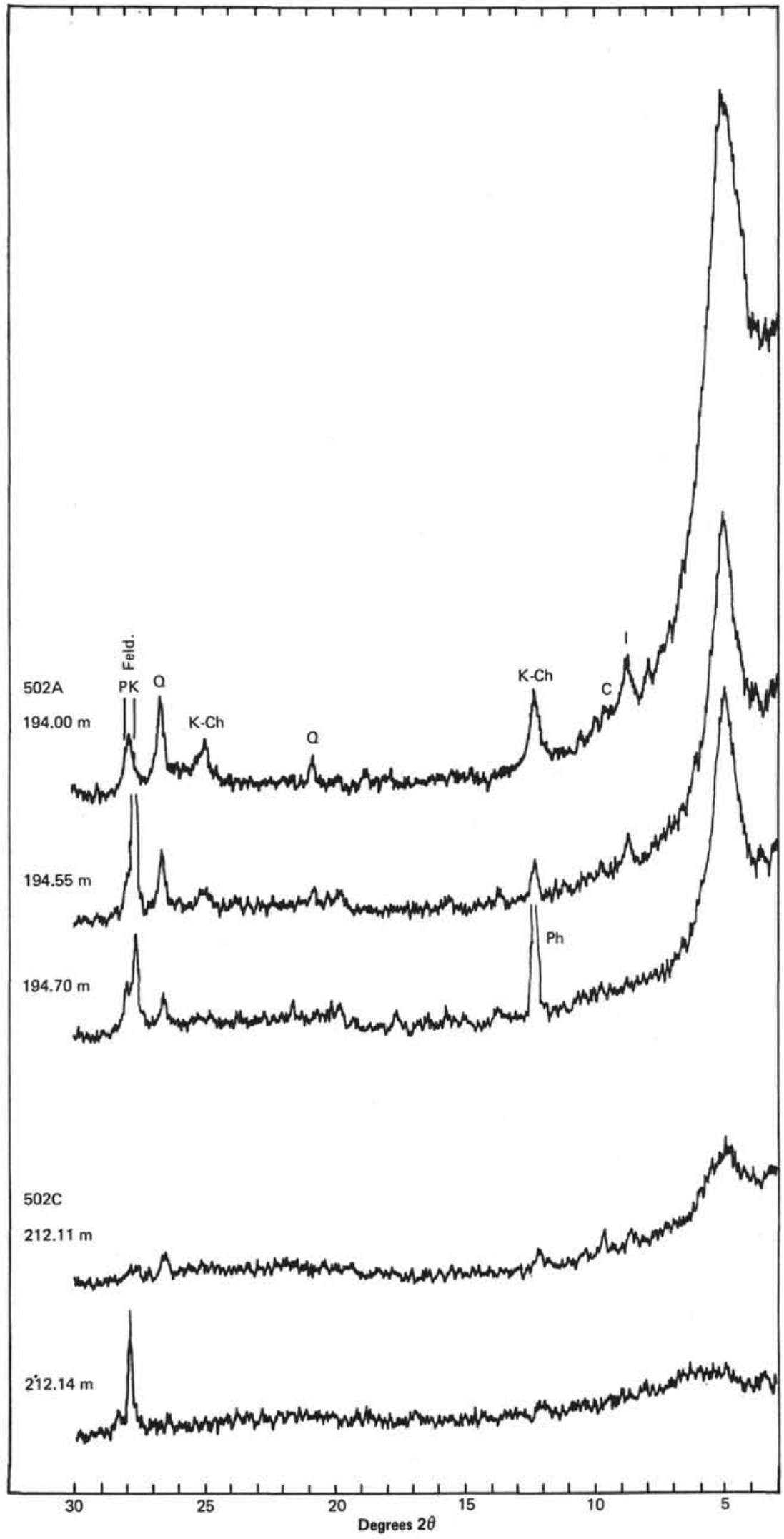

Figure 4. Selected diffractograms (glycolated) for two sets of volcanic ashes. These samples represent the $<37-\mu \mathrm{m}$-size fraction (i.e., both clay and silt fraction) of the acid insoluble residue. (Peaks indicated are: $\mathrm{S}=$ smectite, $\mathrm{I}=$ illite, $\mathrm{C}=$ clinoptilolite, $\mathrm{K}-\mathrm{Ch}=$ kaolinite/chlorite, $\mathrm{Ph}=$ phillipsite, $\mathrm{Q}=$ quartz. Sample designations are given by hole and sub-bottom depth.) 


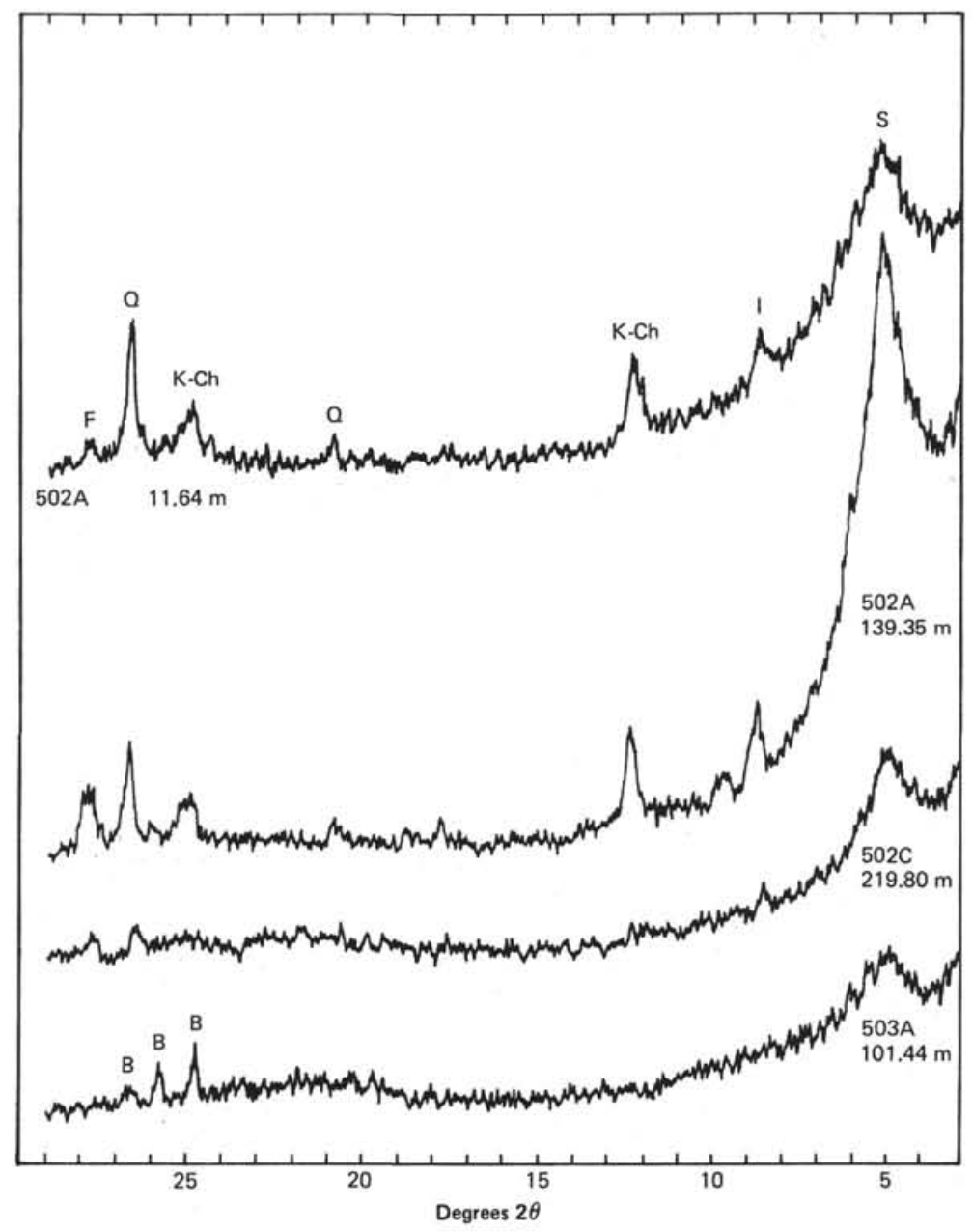

Figure 5. Representative diffractograms (glycolated) for the lithic facies of Leg 68. These samples represent the $<37-\mu \mathrm{m}$-size fraction (i.e., both clay and silt tractions) of the acid insoluble residue. (Peaks indicated are: $\mathrm{S}=$ smectite, $\mathrm{I}=\mathrm{il}$ lite, $\mathrm{K}-\mathrm{Ch}=$ kaolinite/chlorite, $\mathrm{Q}=$ quartz, F = feldspar, B = barite. Sample designations are given by hole and sub-bottom depth.)

siliceous-calcareous ooze, with color and carbonate cycles throughout but exhibiting only minor compositional changes. Examination of smear slides of sediments from Site 503 indicated little volcanic glass and no zeolite minerals.

The sediments of Site 503 are referred to herein as the marine authigenic-hydrothermal facies. Smectite of poor crystallinity is the predominant clay mineral with only occasional and minor contributions of kaolinite. Only one sample $(127.07 \mathrm{~m})$ contained appreciable amounts of kaolinite and illite, but even here these minerals accounted for less than $10 \%$ of the clay fraction. Other minerals of the clay fraction detected in trace amounts include phillipsite, clinoptilolite, barite, quartz, alkali feldspar, cristobalite, and amphibole. Barite is the dominant crystalline component of the silt fraction, occurring throughout the sediment section. In smear slides, however, barite could not be identified. The broad peak $\left(\sim 22^{\circ} 2 \theta\right)$ of opal A (biogenic silica) is also present in all samples throughout the section.

\section{DISCUSSION}

\section{Stratigraphy}

Our primary goal on Leg 68 was to demonstrate the effectiveness of the HPC in recovering a complete and undisturbed section of unconsolidated sediment. This goal was accomplished by coring a series of closely spaced holes in the immediate vicinity of previously drilled sites and establishing a detailed stratigraphic correlation between holes. Besides intercalibration of bioand magneto-stratigraphy, this test also provided an opportunity to demonstrate the value of lithologic correlation for stratigraphic analysis.

For Site 502, four lithologic horizons can be pinpointed and used with confidence for stratigraphic correlation. Three of these are related to volcanic ash layers. In the upper portion of the sedimentary section, a "gray" ash was distinctive and easily correlated between holes. For the two ash "doublets," the spacing of the ashes with respect to depth in the hole is the basis of 
their stratigraphic value. The ashes, however, cannot be correlated to Site 154 because any detailed stratigraphy at that site was destroyed by the rotary drilling process.

This investigation focused on clay mineralogy as a stratigraphic tool. Although consistent trends and various facies are apparent, clay mineral abundance did not provide specific marker horizons for clear stratigraphic correlation. XRD analysis did, however, identify a distinct lithic change based on a crystallinity index (Fig. 2) that was correlative between Site 502 and Site 154. It provides the only lithic horizon that may be positively correlated between sites. The horizon represents an abrupt clay mineral facies change with a terrigenous/Atlantic association (Fig. 5, 502A-11.64 $\mathrm{m}$ and 502A$139.35 \mathrm{~m}$ ) overlying the marine authigenic-volcanic facies (Fig. 5, 502C-219.80 m). The lower units at Sites 154 and 502 are, however, somewhat different in nature. The lower "volcanic-terrigenous" sequence at Site 154 (Edgar et al., 1973) is described as a coarse sand with calc-alkaline volcanic constituents, suggesting a turbidity current origin from a Panama-Costa Rica source. Although the lower unit (Unit D) at Site 502 has a similar composition, it is of much finer grain size, reflecting the site's elevated topographic position above the influence of turbidite sand deposition.

Although lithologically well defined, the facies boundary is apparently not isochronous between sites. The facies change occurs abruptly in the early Pliocene at 167 meters (Hole 154) and approximately 153 meters (Hole 154A), whereas the change occurs in the late Miocene at 201 meters (Holes 502 and 502A). An explanation for this difference is that it reflects the topographic position of both sites on a horst-like uplift, which carries the sites to elevated positions above the influence of bottom transport processes. The different ages for the boundary result from the fact that Site 502 cleared the level of near-bottom transport in late Miocene, prior to Site 154 which cleared that level in early Pliocene. The finer grain size of sediments at Site 502 indicates that this area was above the level of turbidite sand deposition in late Miocene ( $8 \mathrm{~m} . \mathrm{y}$.) but not above a clay-bearing nepheloid layer that might have accompanied the turbidite activity. The uplift of Site 502, therefore, substantially predates that of Site 154, where turbidite deposition continued until early Pliocene.

The apparent difference in time of the facies change may also be explained by the presence of an unidentified unconformity at Site 154 , with sediment representing the latest Miocene and earliest Pliocene removed. Supporting this interpretation are: (1) the site's elevated position in a tectonically active area, (2) the abruptness of the boundary, (3) the boundary's different sub-bottom depths in closely spaced holes at Site 154 , (4) the presence of downhole slumped material throughout Site 154 (Edgar, Saunders, et al., 1973), and (5) the absence of a fine-sediment transition representing material equivalent to that of the lower unit at Site 502 .

\section{Sediment Sources and Facies}

In the western Caribbean Sea noncarbonate marine deposition is controlled by climate, tectonic activity, and rock type in the source areas. The predominant rock type of southern Central America is basic volcanic with associated volcanic sediment of similar composition (Griffin and Goldberg, 1967; Case, 1974). The climate regime is predominantly tropical-humid, and weathering products of this terrane yield abundant smectite, pyroxene, and less abundant quartz to the marine surface sediments. To the southeast, the Colombia Basin is enclosed by the South American landmass, which is drained by the Rio Magdalena, the largest river entering the Caribbean Sea. The Rio Magdalena and its tributaries drain an area of varied igneous, sedimentary, but predominantly metamorphic rock in an extremely variable climate (Banks, 1977; Shagam, 1977). Holocene sediments off the coast of South America are related to crystalline/metamorphic source rocks of the South American borderland (Griffin and Goldberg, 1976). They are distinguished by high quartz concentrations; abundant amphibole, chlorite, and muscovite; low concentrations of smectite; and high quartz/feldspar ratios.

The lower lithic facies at Sites 502 and 154 (Fig. 5, $502 \mathrm{C}-219.80 \mathrm{~m}$ ) resembles a marine/Pacific clay mineral association and is here termed a marine authigenic-volcanic facies. This facies is dominated by poorly crystallized smectite (or mixed-layer smectite/illite); contains relatively little chlorite, kaolinite, or illite; exhibits a low quartz/plagioclase ratio; contains many ash layers and much dispersed ash; and frequently contains secondary zeolite minerals and biosiliceous materials. These characteristics are common in sediments showing little terrestrial influence and are similar to those of the South Pacific (Griffin and Goldberg, 1963; Heath, 1969). This facies may be formed by the alteration of volcanic debris in a marine environment, the smectite and zeolite minerals being derived by authigenic processes.

The sediment section composing the terrigenous/ Atlantic association (Units A, B, and C) at Site 502 and its Sites 154 equivalent, the upper "pelagic sequence," reflect a late Miocene to Holocene transition in source area from a basaltic to a predominantly metamorphic provenance. Figure $5(502 \mathrm{~A}-11.64 \mathrm{~m}$ and $502 \mathrm{~A}-139.35$ m) illustrates the XRD traces for the end members of this transition. The excellent smectite crystallinity of the lower portion of this facies is formed by the subarealhumid weathering of the basaltic rocks of Panama and Costa Rica. Smectite of terrigenous origin is also the major clay constituent in the Panama Basin off western Panama and Costa Rica (Heath et al., 1974). Transiting upward the sediment becomes increasingly continental in character, with increases in the quartz/plagioclase ratio and in the proportion of kaolinite, chlorite, and illite to smectite. This change is ascribed to the growing influence of the Rio Magdalena, diluting the smectite derived from southern Central America. With the change in source area, the character of the smectite contribution also changes; the variable South American climate producing a less well-crystallized smectite or more mixedlayered smectite/illite from the metamorphic terrane.

We do not consider the diagenetic alteration of vitric ash layers or dispersed vitric ash debris to be an important source of the smectite in this facies (following Cham- 
ley, 1979, 1980). In many instances, smectite abundance seems actually to be diluted by volcanic material (Figs. $2,4)$. The ash layers in this section represent discrete events and there is relatively little volcaniclastic debris identified in the sediments between the ash layers. Furthermore, vitric particles appear fresh and unaltered. Some diagenetic activity, however, is indicated by the presence of small amounts of phillipsite and/or clinoptilolite throughout the section. Zeolite minerals appear in appreciable amounts only where restricted to the distinct ash layers or to the mixed sediment immediately above. We conclude that in the Colombia Basin the sediments of this facies (the terrigenous/Atlantic) reflect a transition in source area from the subareal weathering of the volcanic terrane of Central America to the south and west, with an increasing contribution from the crystalline rocks of the South American landmass to the southeast.

\section{Closing the Panamanian Seaway}

The stratigraphic position of the sediments of Sites 502 and 154 place them within the time frame of the emergence of the Isthmus of Panama. Based on evidence of the interchange of vertebrate land fauna, Stirton (1950) and Whitmore and Stewart (1965) place the final emergence of the land bridge in the middle to late Pliocene. Sloan (1980) places the final uplift of the land bridge between Panama and Colombia at $2.8 \pm 0.2 \mathrm{Ma}$ at the Bolivar Trench. Marine biostratigraphic evidence also fixes the emergence in the middle to late Pliocene; Saito (1976) at 3.5 Ma and Keigwin (1978) at 3.1 Ma. The completion of the land bridge, therefore, occurs during deposition of the upper facies at Site 502. Although no particular effect is noted in the noncarbonate fraction, I suspect that the change in surface-current regime influenced carbonate productivity, as suggested by Edgar, Saunders, et al. (1973), and is reflected in the increased carbonate content through the Pliocene section (site chapter, Site 502).

The process of closing the isthmus, however, certainly took place in stages over a considerable length of time previous to late Pliocene (Case, 1974; Heath and van Andel, 1973; Holcombe and Moore, 1977). Shoaling and constriction of the waterway occurred in middle to late Miocene, concomitant with renewed volcanic activity in Central America (Fig. 6) (see Ledbetter, this volume). Apparently the lower facies of the Colombia Basin, with its high rate of noncarbonate accumulation has its origin in the large influx of volcanogenic debris associated with this tectonic activity. Erosion and transport from the nascent volcanic terrane of Panama and Costa Rica were apparently rapid enough to allow pyroxene and feldspar sands (Site 154) to survive the subtropical weathering processes. At Site 502, the result is the marine authigenic-volcanic facies derived from the alteration of volcanic debris in the marine environment. At this time little terrestrial debris (quartz, illite, chlorite, or kaolinite) entered the Colombia Basin from the South American region. I suspect that the oceanic regime was dominated by strong water movement sweeping fine sediment from northern South America west- ward through the Panamanian waterway (Fig. 6). Holcombe and Moore (1977) present evidence for a strong east-to-west wind-driven current, a much-strengthened Caribbean Current (of Wust, 1966), producing Late Cretaceous to Miocene nondeposition on the floor of the eastern Caribbean.

In the western Caribbean, Kim and Buffler (1980) date the initiation of the thick upper wedge of the Magdalena Fan as late Miocene-Pliocene. Shoaling of the waterway in late Miocene through Pliocene time would have weakened the deep and intermediate flow of the Caribbean Current, allowing continental debris from the Rio Magdalena to penetrate and deposit within the central Colombia Basin. This event is thus correlated with the lithofacies change, in which authigenic smectite and zeolite minerals were swamped by increasingly terrigenous sediment. The occurrence of continental debris at this horizon thus signals the cessation of strong westward circulation through the Caribbean, although surface-water communication between the Atlantic and $\mathrm{Pa}$ cific probably continued into the late Pliocene.

Evidence of the history of the Panamanian Seaway based on the rate of sediment accumulation (Fig. 18, site chapter, Site 502 ) is, unfortunately, complicated by the site's position on a local tectonic uplift. The decrease in the noncarbonate accumulation rate subsequent to early Pliocene may only reflect the rising position of the site. The clay mineral composition, however, clearly signals the first arrival of sediment from the South American landmass and thus the constriction of the Panamanian Seaway.

\section{Pacific Sediments}

Sites 503 and 83 are located over $1500 \mathrm{~km}$ to the west of the Isthmus of Panama on the northern flank of the Galapagos Rise. The sediment is a uniform siliceouscalcareous ooze with little ash. The uniform nature of the sediment section provides little opportunity for lithic correlation between the sites.

The lithic facies, here termed the marine authigenichydrothermal facies is dominated by poorly crystallized smectite with only trace amounts of phillipsite, clinoptilolite, and alkali feldspar. Barite is abundant in the silt fraction throughout the sediment section but cannot be identified by smear slide examination. The XRD trace (Fig. 5, 503A-101.44 m) is distinctly different from those of the Caribbean sites. The $17 \AA$ peak for smectite (glycolated) is broad and low, suggesting poor crystallinity, a high degree of mixed layering, or the presence of a ferruginous smectite (nontronite; Rateev et al., 1980). Additionally, the broad, diffuse reflection band $\left(15-25^{\circ} 2 \theta\right)$ of biogenic opal is always evident.

The absence of other clay or silt minerals reflects the site's position on a bathymetric high and its great distance from continental sources. However, in the sediment section representing the Miocene/Pliocene boundary (sub-bottom depth of 120 to $160 \mathrm{~m}$ ), minor amounts of kaolinite, illite, and fine quartz are noted, indicating some terrigenous contribution. Although Holocene terrestrial sediments from South and Central America are dispersed over distances of several hundred kilometers 


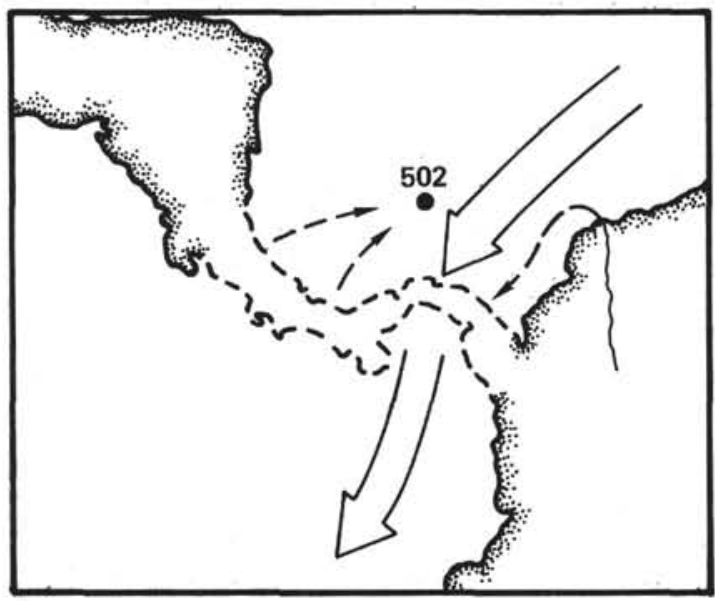

A. Phase I - late Miocene. The marine authigenicvolcanic facies has its origin in the volcanic debris generated by the late Miocene volcanic acitivity in Central America. Terrestrial material from the South American land mass is prevented from reaching the Central Colombia Basin by the through-flowing $\mathrm{Ca}$ ribbean Current.

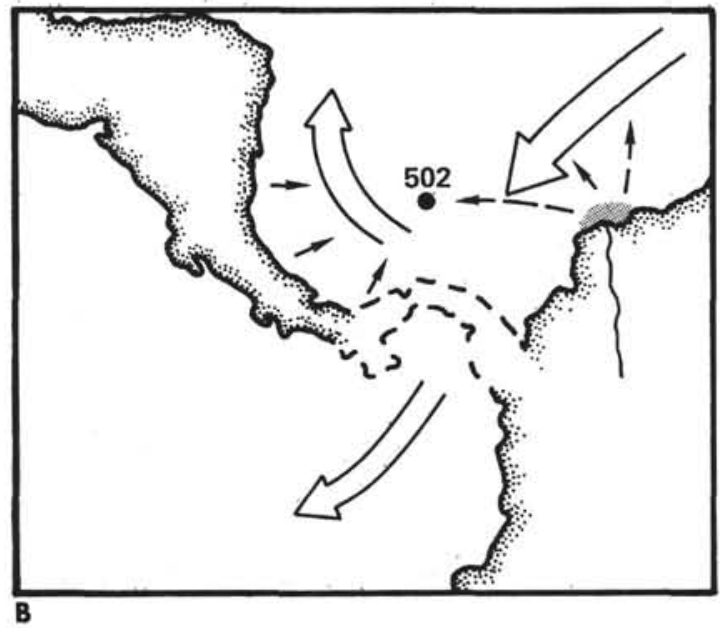

B. Phase II - late Miocene-Pliocene. Shoaling and constriction of the Panamanian Waterway weaken the deep and intermediate flow of the Caribbean Current. This allows continental debris to penetrate and deposit in the Central Colombian Basin.

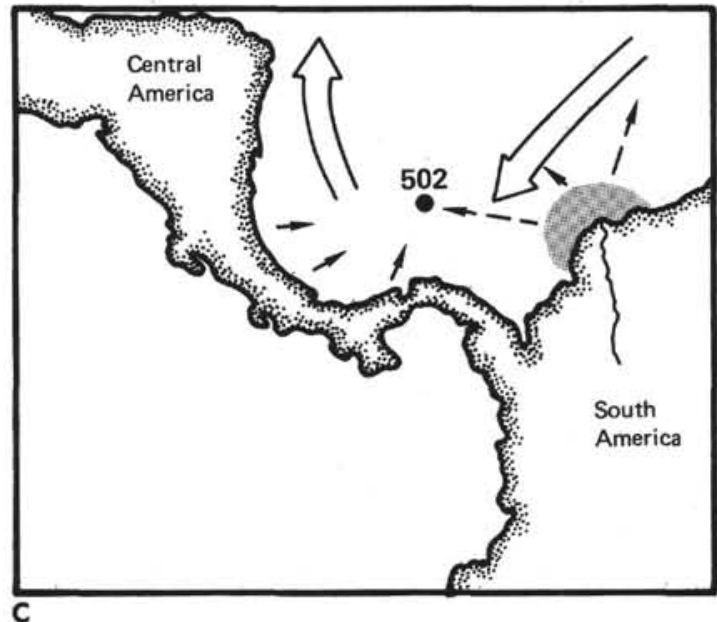

C. Phase III - Iate Pliocene-Recent. Final closure of the isthmus of Panama arrests west flow of the Caribbean Current. Sediment if the Columbia Basin becomes increasingly terrigenous in character.

Figure 6. Model of paleoceanographic events associated with the emergence of the Isthmus of Panama. (Broad arrows indicate current flow; dashed arrows indicate sediment transport; the Magdalena Fan is shaded.) 
by intermediate-depth and near-bottom currents, very little of this material reaches the area west of the Galapagos Islands (Heath et al., 1974; Plank et al. 1973). It is possible that changing current regimes (Malfait and van Andel, 1980), perhaps initiated by the emergence of the Panamanian Isthmus in the Miocene-Pliocene time frame, may have allowed the transport of small amounts of terrigenous debris to Site 503. Atmospheric transport is another obvious (and perhaps most likely) method for the introduction of this material (see Rea, this volume). Other than that minor terrestrial contribution, the fine fraction consists almost exclusively of smectite (nontronite).

There is no immediate continental source for the large amounts of smectite at this location. Griffin and Goldberg (1963) suggest that smectite in the South Pacific is formed in situ from alteration of volcanic debris. For these sites, however, little volcanic material is evident in the sedimentary section. The virtual absence of zeolite minerals and alkali feldspar also differentiate these sediments from the "oceanic" facies of Heath (1969). The most likely origin of this authigenic smectite is the low-temperature combination of $\mathrm{Fe}$ oxyhydroxide and silica, as suggested by Heath and Dymond (1977) for the Bauer Basin and Hein et al. (1979) for the north equatorial Pacific. All constituents are readily available for this reaction; $\mathrm{Fe}$ in the form of $\mathrm{Fe}$ hydroxide or oxyhydroxide may be derived from hydrothermal activity of the Galapagos Rise and silica from the dissolution of the abundant siliceous microfossils. It is noteworthy that these sediments contain appreciable amounts of barite as do the Bauer Deep sediments (Heath and Dymond, 1977). Barium, however, is closely associated with both biological and hydrothermal processes (Boström et al., 1976). I have designated the lithic facies at this site as a marine authigenic-hydrothermal facies. It consists almost exclusively of authigenic minerals: poorly crystallized smectite (probably nontronite), barite, and minor zeolites and feldspar. This is accompanied by biogenic silica throughout the section and occasionally by minor eolian constituents (kaolinite, illite, and quartz).

\section{CONCLUSIONS}

Three lithic facies have been encountered in this investigation:

1) A terrigenous/Atlantic association represented by the upper 201 meters at Site 502. This facies reflects a late Miocene to Holocene transition in source area from the basaltic terrane of Panama-Costa Rica to the increasing dominance of continental debris from South America contributed by the Rio Magdalena. The facies is distinguished by the presence of continental material (illite, kaolinite, chlorite, and quartz) as well as wellcrystallized smectite.

2) A marine authigenic-volcanic facies represented by the late Miocene sediment section below 201 meters at Site 502. This facies resembles a marine/Pacific association and originates by the authigenic alteration of volcanic debris in a marine environment. The facies is distinguished by little continental material, a low quartz/ plagioclase ratio, poorly crystallized smectite, the presence of volcanic ash, zeolite minerals, and biosiliceous microfossils.

3) A marine authigenic-hydrothermal facies represented by the sediments of Site 503. This facies originates by the low-temperature combination of $\mathrm{Fe}$ oxyhydroxide and silica. It is characterized by poorly crystallized smectite (nontronite) and by the presence of barite, biosiliceous material, and only traces of zeolite minerals. At Site 503, continental and volcanic debris are rare.

The changing character of the lithic facies in the western Caribbean reflects the oceanographic consequences of the emergence of the Panamanian land bridge. From late Miocene through Pliocene time, progressive shoaling and constriction of the waterway weakened and eventually eliminated the deep and intermediate flow of the Caribbean Current into the Pacific. The elimination of this current allowed continental debris to be deposited in the central Colombian Basin, replacing the marine authigenic-volcanic facies of late Miocene.

The upper 200 to 300 meters of unconsolidated deepsea sediment are now accessible in an undisturbed condition through the use of the hydraulic piston corer. This instrument has greatly improved our capability to employ lithologic criteria for detailed stratigraphic analysis and paleoceanographic interpretation.

\section{ACKNOWLEDGMENTS}

I wish to thank the Deep Sea Drilling Project for the opportunity to participate on Leg 68 and my fellow shipboard scientists for their stimulating collaboration and unflagging good humor. I am grateful to Drs. Floyd McCoy and V. Kolla (L.D.G.O.), who read the manuscript and offered constructive comments. Thanks are also due to John Titus and Andrew Zimmerman for assistance in the XRD laboratory. This research was supported in part by the National Science Foundation, Grant OCE 80-08236. I also wish to thank Union College for making available the facilities of the Cooledge X-ray Laboratory.

\section{REFERENCES}

Banks, P. O., 1977. Basement rocks bordering the Gulf of Mexico and the Caribbean Sea. In Nairn, A. E. M., and Stehli, F. G. (Eds.), The Ocean Basins and Margins (Vol. 3): New York (Plenum Press), 181-199.

Biscaye, P. E., 1964. Distinction between kaolinite and chlorite in recent sediments by X-ray diffraction. Am. Mineral., 49:12811289.

, 1965. Mineralogy and sedimentation of Recent deep-sea clay in the Atlantic Ocean and adjacent seas and oceans. Geol. Soc. Amer. Bull., 76:803-831.

Boström, K., Joensuu, O., Valdés, S., Charm, W., and Glaccum, R., 1976. Geochemistry and origin of East Pacific sediments sampled during DSDP Leg 34. In Yeats, R. S., Hart, S. R., et al., Init. Repts. DSDP, 34: Washington (U.S. Govt. Printing Office), 559-574.

Case, J. E., 1974. Uceanic crust forms oasement of eastern Panama. Geol, Soc. Am. Bull., 85:645-652.

Chamley, H., 1979. North Atlantic clay sedimentation and paleoenvironment since the Late Jurassic. In Talwani, M., Hay, W., and Ryan, W. B. F. (Eds.), Deep Drilling Results in the Atlantic Ocean, (Maurice Ewing Series 3): New York (American Geophysical Union), 342-361.

1980. Clay sedimentation and paleoenvironment in the Shikoku Basin since the middle Miocene (Deep Sea Drilling Project Leg 58, North Philippine Sea). In Kleın, G. deV., Kobayashi, K., et al., Init. Repts. DSDP, 58: Washington (U.S. Govt. Printing Office), 669-681. 
Edgar, N. T., Saunders, J. B., et al., 1973. Init. Repts. DSDP, 15: Washington (U.S. Govt. Printing Office).

Eslinger, E. V., and Savin, S. M., 1976. Mineralogy and $\mathrm{O}^{18} / \mathrm{O}^{16}$ ratios of fine-grained quartz and clay from Site 323. In Hollister, C. D., Craddock, C., et al., Init. Repts. DSDP, 35: Washington (U.S. Govt. Printing Office), 489-496.

Gibbs, R. J., 1968. Clay mineral mounting techniques for X-ray diffraction analysis: A discussion. J. Sediment. Petrol., 38:242-244.

Griffin, J. J., and Goldberg, E. D., 1963. Clay mineral distribution in the Pacific Ocean. In Hill, M. N. (Ed.). The Sea (Vol. 3): New York (Interscience), 728-741.

1967. Recent sediments of Caribbean Sea. Mem. Am. Assoc. Pet. Geol., 11:258-268.

Hayes, J. B., 1973. Clay petrology of mudstones, Leg 18, Deep Sea Drilling Project. In Kulm, L. D., von Huene, R., et al., Init. Repts. DSDP, 18: Washington (U.S. Govt. Printing Office), 903-914.

Hays, J. D., et al., 1972. Init. Repts. DSDP, 9: Washington (U.S. Govt. Printing Office).

Heath, G. R., 1969. Mineralogy of Cenozoic deep-sea sediments from the equatorial Pacific Ocean. Geol. Soc. Am. Bull., 80:1997-2018.

Heath, G. R., and Dymond, J., 1977. Genesis and transformation of metalliferous sediments from the East Pacific Rise, Bauer Deep, and Central Basin, northwest Nazca Plate. Geol. Soc. Amer. Bull., 88:723-733.

Heath, G. R., Moore, T. C., Jr., and Roberts, G. L., 1974. Mineralogy of surface sediments from the Panama Basin, eastern equatorial Pacific. J. Geol., 82:145-160.

Heath, G. R., and van Andel, Tj. H., 1973. Tectonics and sedimentation in the Panama Basin: Geologic results of Leg 16, Deep Sea Drilling Project. In van Andel, Tj. H., Heath, G. R., et al., Init. Repts. DSDP, 16: Washington (U.S. Govt. Printing Office), 899-914.

Hein, J. R., Yeh, H -W., and Alexander, E., 1979. Origin of iron-rich montmorillonite from the manganese nodule belt of the north equatorial Pacific. Clays Clay Miner., 27:185-194.

Holcombe, T, L., and Moore, W. S., 1977. Paleocurrents in the eastern Caribbean: Geologic evidence and implications. Mar. Geol., 23:35-56.
Keigwin, L. D., Jr., 1978. Pliocene closing of the Isthmus of Panama, based on biostratigraphic evidence from nearby Pacific Ocean and Caribbean Sea cores. Geology, 6:630-634.

Kim, H., and Buffler, R. T., 1980. Seismic stratigraphy of the Magdalena Fan area, Colombia Basin. Abstracts and Prog., Geol. Soc. Am., 12:462.

Malfait, B. T., and van Andel, Tj. H., 1980. A modern oceanic hard ground on the Carnegie Ridge in the eastern equatorial Pacific. Sedimentology, 27:467-496.

Plank, W. S., Zaneveld, J. R. V., and Pak, H., 1973. Distribution of suspended matter in the Panama Basin. J. Geophys. Res., 78: 7113-7121.

Rateev, M. A., Timofeev, P. P., and Rengarten, N. V., 1980. Minerals of the clay fraction in Pliocene-Quaternary sediments of the east equatorial Pacific. In Rosendahl, B. R.. Hekinian, R., et al., Init. Repts. DSDP, 54: Washington (U.S. Govt. Printing Office), 307-318

Reynolds, R. C., Jr., and Hower, J., 1970. The nature of interlayering in mixed-layer illite-montmorillonites. Clays and Clay Min., 18: 25-36.

Saito, T., 1976. Geologic significance of coiling direction in the planktonic foraminifera Pulleniatina. Geology, 4:305-309.

Shagam, R., 1977. The northern termination of the Andes. In Nairn, A. E. M., and Stehli, F. G. (Eds.), The Ocean Basins and Margins (Vol. 3): New York (Plenum Press), 325-420.

Sloan, R. E., 1980. The late Cenozoic Caribbean bridge and barrier. Abstracts and Prog., Geol. Soc. Am., 12:523.

Stirton, R. A., 1950. Late Cenozoic avenues of dispersal for terrestrial animals between North America and South America. Geol. Soc. Am. Bull., 61:1541-1542.

Whitmore, F. C., Jr., and Stewart, R. H., 1965. Miocene mammals and Central American seaways. Science, 148:180-185.

Wüst, G., 1964. Stratification and circulation in the Antillean-Caribbean Basins: New York (Columbia University Press).

Zimmerman, H. B., 1977. Clay mineral stratigraphy and distribution in the South Atlantic Ocean. In Supko, P. R., Perch-Nielsen, K., et al., Init. Repts. DSDP, 39: Washington (U.S. Govt. Printing Office), 395-405. 